\title{
PENGEMBANGAN MODUL BERBASIS INKUIRI TERBIMBING PADA MATERI KIMIA LARUTAN PENYANGGA UNTUK MENINGKATKAN KETERAMPILAN BERPIKIR KRITIS SISWA KELAS XI SMA DI KARANGANYAR
}

\author{
Sarry Saraswaty ${ }^{1}$, Mohammad Masykuri $^{2}$, Sri Mulyani $^{3}$ \\ ${ }^{1}$ Program Studi Magister Pendidikan Sains FKIP Universitas Sebelas Maret \\ Surakarta, 57126, Indonesia \\ sara_saras92@yahoo.com \\ ${ }^{2}$ Program Studi Magister Pendidikan Sains FKIP Universitas Sebelas Maret \\ Surakarta, 57126, Indonesia \\ mmasykuri@yahoo.com \\ ${ }^{3}$ Program Studi Magister Pendidikan Sains FKIP Universitas Sebelas Maret \\ Surakarta, 57126, Indonesia \\ srimulyaniuns@gmail.com
}

\begin{abstract}
Abstrak
Penelitian ini merupakan penelitian pengembangan modul yang mempunyai beberapa tujuan yaitu pertama, mengembangkan modul pembelajaran kimia berbasis inkuiri terbimbing pada materi Larutan Penyangga untuk meningkatkan keterampilan berpikir kritis siswa SMA. Kedua, menganalisis kualitas modul pembelajaran kimia berbasis inkuiri terbimbing materi Larutan Penyangga yang dikembangkan. Ketiga, mengetahui efektivitas modul pembelajaran kimia berbasis inkuiri terbimbing materi Larutan Penyangga untuk meningkatkan keterampilan berpikir kritis siswa. Terakhir, mengetahui peningkatan hasil belajar kimia siswa melalui modul kimia berbasis inkuiri terbimbing materi Larutan Penyangga. Hasil penelitian menunjukkan bahwa: pertama, modul dapat meningkatkan keterampilan berpikir kritis sisw. Kedua, kategori modul adalah sangat baik dan layak digunakan oleh siswa dan guru. Ketiga, pembelajaran menggunakan modul efektif digunakan untuk meningkatkan keterampilan berpikir kritis siswa. Terakhir, pembelajaran menggunakan modul dapat meningkatkan hasil belajar aspek pengetahuan siswa.
\end{abstract}

Kata Kunci: modul kimia, inkuiri terbimbing, keterampilan berpikir kritis, larutan penyangga

\section{Pendahuluan}

Pendidikan adalah bekal ilmu yang bermanfaat bagi masa depan siswa. Kunci kesuksesan pada pendidikan, salah satunya adalah proses belajar dan mengajar, keaktifan siswa, serta landasan yang baik dalam pendidikan. Dalam rangka membangun landasan yang lebih baik, pengembangan kurikulum 2013 selain sebagai jawaban terhadap beberapa permasalahan yang terjadi di tingkat sekolah (Kurikulum 2006), juga bertujuan untuk mendorong siswa agar mampu lebih baik dalam melakukan observasi, memiliki keterampilan bertanya, memiliki daya nalar, dan dapat mempresentasikan apa yang diperoleh setelah siswa menerima materi pembelajaran di sekolah (Hosnan, 2014).

Dalam pelaksanaan kurikulum 2013, menggunakan pendekatan saintifik atau pendekatan ilmiah. Penggunaan pendekatan saintifik sangat tepat, khususnya untuk materi kimia karena pendekatan saintifik adalah pembelajaran yang terdiri atas kegiatan mengamati, merumuskan hipotesis, mengumpulkan data dengan berbagai teknik, menganalisis atau mengolah data, serta menarik kesimpulan 
kemudian mengkomunikasikan hasil akhir untuk memperoleh hasil belajar berupa pengetahuan, keterampilan, dan sikap.

Belajar dapat dipandang sebagai proses yang diarahkan kepada tujuan dan proses berbuat melalui berbagai pengalaman (Hosnan, 2014). Dalam suatu proses belajar dan mengajar, diperlukan penataan lingkungan belajar, penyediaan alat - alat belajar, dan sumber belajar yang baik serta sesuai dengan materi ajar agar hasil belajar siswa dapat optimal. Adapun hasil belajar siswa secara keseluruhan dibagi dalam beberapaaspek, yaitu aspek berpikir kritis, aspek pengetahuan, aspek sikap, dan aspek keterampilan.

Proses belajar dan mengajar adalah suatu interaksi antara guru dan siswa yang berlangsung untuk mendapatkan suatu ilmu atau informasi baru. Dalam hal ini, guru berperan penting untuk membantu siswa memperoleh atau menemukan suatu informasi baru agar dapat tersimpan dalam memori jangka panjang siswa. Namun dalam kenyataannya, siswa masih kurang aktif dan kurang memahami materi yang diberikan oleh guru. Salah satunya adalah materi kimia.

Menurut Keenan (1986), ilmu kimia merupakan produk (pengetahuan kimia yang berupa fakta, teori, prinsip, hukum) temuan saintis dan proses (kerja ilmiah), oleh sebab itu dalam penilaian dan pembelajaran kimia harus memperhatikan karakteristik ilmu kimia sebagai produk dan proses.

Dalam proses penyampaian materi kimia kepada siswa diperlukan suatu penyajian materi yang menarik dan tidak monoton. Untuk mewujudkannya, diperlukan guru yang mempunyai kualitas kompetensi pedagogik yang baik. Kualitas kompetensi pedagogik yang baik adalah kemampuan guru dalam melaksanakan perencanaan dan pelaksanaan pembelajaran. Dalam melaksanakannya, guru dituntut untuk merencanakan suatu pembelajaran menggunakan suatu model dan media pembelajaran yang tepat untuk mendukung tercapainya tujuan pembelajaran.

Pengunaan media dapat mempermudah pemahaman materi dan meningkatkan hasil belajar siswa sehingga dapat meningkatkan hasil belajar siswa. Landasan teori mengenai penggunaan media dalam proses belajar adalah Kerucut Pengalaman Dale (Dale 'Cone of Experience).

Media yang dapat digunakan salah satunya adalah modul. Modul adalah sebagai bahan belajar dimana pembacanya dapat belajar secara mandiri dan membantu siswa membangun pengetahuannya (Daryanto, 2013). Modul adalah suatu cara pengorganisasian materi pelajaran yang memperhatikan fungsi pendidikan.

Pada penelitian ini, modul dikembangkan berdasarkan model penelitian dan pengembangan Borg \& Gall (1983) berbasis inkuiri terbimbing untuk meningkatkan keterampilan berpikir kritis pada materi Larutan Penyangga. Inkuiri adalah suatu proses untuk mengidentifikasi masalah, mengkritisi percobaan, perencanaan, menyelidiki suatu dugaan, mencari informasi, membangun model, berdebat dengan teman sebaya, dan membentuk argumen yang koheren (Linn, Davis, \& Bell, 2004). Sehingga dapat dikatakan bahwa pembelajaran inkuiri sesuai dengan pembelajaran sains, khususnya kimia karena menekankan pada keaktifan siswa selama proses pembelajaran untuk menemukan jawaban yang dibutuhkan.

Tujuan dari penelitian ini adalah untuk mengembangkan modul kimia berbasis inkuiri terbimbing untuk meningkatkan keterampilan berpikir kritis siswa. Tahapan sintaks pembelajaran inkuiri terbimbing: (1) pembukaan dan imersi, (2) eksplorasi, (3) identifikasi, (4) pengumpulan data, (5) penciptaan, (6) presentasi, dan (7) evaluasi (Kuhlthau, Maniotes, \& Casparl, 2012). Indikator keterampilan berpikir kritis, antara lain: a) inferensi; b) mengenal asumsi; c) deduksi; d) interpretasi; dan e) evaluasi argumen 
(Piaw) (Rusyana, 2014).

Keterampilan berpikir kritis, menurut Dewey adalah suatu pertimbangan yang aktif, terus-menerus, dan teliti mengenai sebuah pengetahuan yang diterima dipandang dari sudut-sudut alasan-alasan yang mendukungnya dan kesimpulankesimpulan lanjutan yang menjadi kecenderungannya (Fisher, 2009).

Tawil dan Liliasari mengatakan bahwa implementasi keterampilan berpikir kritis dalam pembelajaran IPA atau Ilmu Pengetahuan Alam, khususnya pada pelajaran kimia, fisika, dan biologi mempunyai indikator-indikator tersendiri yang telah disesuaikan dengan karakter pelajaran IPA tersebut (Tawil \& Liliasari, 2013).

Modul pembelajaran inkuiri terbimbing yang dikembangkan berisikan tentang langkah-langkah pembelajaran inkuiri terbimbing yang dapat digunakan siswa pada saat proses pembelajaran berlangsung dan indikator-indikator keterampilan berpikir kritis. Modul ini akan melatih siswa dalam berpikir kritis untuk menyelesaikan masalah-masalah yang disajikan di dalam modul dan mempelajari konsep materi yang diberikan secara mandiri tetapi guru tetap memberikan bantuan untuk membantu siswa dalam menemukan konsep.

Penggunaan modul dirasa sangat perlu bagi guru maupun siswa. Hal ini dikarenakan modul merupakan suatu media pembelajaran yang penyusunannya disesuaikan dengan materi dan strategi belajar yang diperlukan untuk membantu siswa mempermudah pemahaman dalam materi Larutan Penyangga. Guru juga terbantu dengan penggunaan modul karena isi modul yang terstruktur dan tampilan yang menarik sehingga dapat meningkatkan hasil belajar siswa terhadap materi Larutan Penyangga.

\section{Metode Penelitian}

Penelitian yang dilakukan merupakan penelitian dan pengembangan (Research and Development) yaitu pengembangan modul berbasis inkuiri terbimbing untuk meningkatkan keterampilan berpikir kritis pada materi Larutan Penyangga.

\section{Studi Pendahuluan}

Studi pendahuluan yang dilakukan adalah studi pustaka, survei lapangan, dan analisis kebutuhan. Studi pustaka dilakukan untuk mengumpulkan berbagai informasi terhadap modul ajar, pembelajaran inkuiri terbimbing, modul berbasis inkuiri terbimbing, hasil belajar siswa aspek pengetahuan, sikap, dan keterampilan, serta aspek keterampilan berpikir kritis.

Analisis dilakukan untuk pemetaan dan mengetahui aspek-aspek dalam:

1. Kompetensi Inti dan Kompetensi Dasar pada materi Larutan Penyangga.

2. Keterampilan berpikir kritis siswa:
a) Inferensi; b) Mengenal asumsi;
c) Deduksi; d) Interpretasi; dan
e) Evaluasi argumen

3. Rancangan Pelaksanaan Pembelajaran (RPP) Kimia yang menggunakan indikator keterampilan berpikir kritis.

4. Keterkaitan modul ajar kimia dengan tahapan sintaks pembelajaran inkuiri terbimbing.

Subjek penelitian pada survei lapangan adalah siswa dan guru. Informasi diperoleh dari observasi awal siswa dan angket penguasaan kelompok materi soal kimia serta wawancara guru dan siswa mengenai materi ajar. Informasi dari survei lapangan berupa data kualitatif dan dianalisis menggunakan analisis deskriptif.

\section{Tahap Pengembangan}

Pada tahap pengembangan meliputi:

1. Tahap Perencanaan

meliputi kegiatan yang berhubungan dengan penyiapan rancangan awal penyusunan modul berbasis inkuiri terbimbing yang menggunakan indikator keterampilan berpikir kritis dan 
menyiapkan prosedur penelitian untuk uji kelayakan produk.

2. Tahap Pengembangan Rancangan Awal Produk meliputi tahapan sintaks pembelajaran inkuiri terbimbing, Indikator keterampilan berpikir kritis, identifikasi pada Kompetensi Dasar (KD) 3.13 Mendeskripsikan sifat larutan penyangga dan peranan larutan penyangga dalam tubuh makhluk hidup, perangkat pembelajaran yang meliputi silabus, Rancangan Pelaksanaan Pembelajaran (RPP) dan instrumen penilaian.

3. Validasi Desain uji validasi ahli yang terdiri dari validasi materi ajar, validasi desain dan keterbacaan modul ajar, validasi pengembang modul ajar, serta validasi pengembang soal kognitif. Kualifikasi yang menjadi validator minimal memiliki Sarjana Strata 2/S2 atau ahli di bidangnya. Revisi produk dilakukan berdasarkan hasil uji validasi oleh validator untuk ditentukan apakah modul yang dikembangkan sudah layak atau perlu perbaikan sebelum dilakukan langkah selanjutnya.

4. Uji Coba Produk uji coba dilakukan dengan 3 skala, yaitu uji coba skala kecil oleh 12 siswa, uji coba skala menengah oleh 12 , dan uji coba skala luas oleh 77 siswa. Analisis dilakukan terhadap aspek keterampilan berpikir kritis, aspek pengetahuan, aspek sikap, dan aspek keterampilan.

\section{Analisis Data}

Jenis data dalam penelitian ini adalah data kuantitatif yang berupa hasil belajar dan keterampilan berpikir kritis siswa materi larutan penyangga dan persentase capaian uji coba produk serta data kualitatif yang berupa validasi produk dan hasil uji coba produk.

a) Analisis Deskriptif Kualitatif

Analisis kualitatif dilakukan terhadap analisis angket yang diberikan kepada guru dan siswa serta analisis modul. b) Analisis Aspek Keterampilan Berpikir Kritis

c) Analisis Kuantitatif

Analisis kuantitatif dilakukan terhadap instrumen soal aspek pengetahuan, aspek sikap, dan aspek keterampilan.

d) Uji Efektifitas Produk

Efektifitas produk yang akan diuji adalah selisih nilai pretest dan posttest siswa dari aspek keterampilan berpikir kritis.Uji yang akan digunakan adalah uji $\mathrm{T}$.

\section{Hasil Penelitian dan Pembahasan}

Studi pustaka dilakukan meliputi analisis terhadap kompetensi dasar, model pembelajaran inkuiri terbimbing, dan sumber serta media belajar yang digunakan di sekolah.

\section{Pengembangan Produk}

Sebelum melakukan pengembangan terhadap produk, peneliti terlebih dahulu melakukan analisis kebutuhan terhadap guru dan siswa melalui angket yang diberikan kepada keduanya. Analisis kebutuhan dilakukan untuk mengetahui kebutuhan dan karakter dari modul yang akan dikembangkan berdasarkan hasil angket.

Setelah peneliti melakukan studi pendahuluan, analisis kebutuhan, dan mengetahui masalah yang ada di lapangan, peneliti mencarikan solusi untuk permasalahan tersebut. Solusi yang peneliti simpulkan adalah pengembangan suatu produk media cetak berupa modul. Tahap perencanaan draft modul dilakukan agar modul yang akan dikembangkan dapat membantu siswa dan sesuai dengan tujuan semula.

Adapun hasil perencanaan draft modul yang akan dikembangkan dapat dideskripsikan ke dalam beberapa komponen yaitu cover modul bagian luar, cover modul bagian dalam, halam francis, isi modul, daftar pustaka, dan kunci jawaban.

Setelah desain awal modul dibuat, dilakukan pengembangan draft awal modul sesuai dengan tahap perencanaan. Hasil dari 
pengembangan draft awal modul menghasilkan suatu modul awal yang kemudian dilakukan validasi. Validasi dilakukan terhadap modul dan juga instrumen pembelajaran (RPP beserta penilaian sikap, ketrampilan, dan pengetahuan). Adapun validator modul terdiri dari ahli media, materi, desain pembelajaran, bahasa, dan guru mata pelajaran kimia. Kemudian modul diuji cobakan tiga kali kepada siswa.

Modul kimia berbasis inkuiri terbimbing yang telah direvisi sesuai saran dan masukan dari keseluruhan hasil penilaian angket kelayakan modul oleh ahli, guru, dan siswa disebut dengan produk akhir dari pengembangan yang dilakukan. Produk akhir berupa modul kimia berbasis inkuiri terbimbing materi Larutan Penyangga layak untuk digunakan oleh siswa dan guru dalam pembelajaran karena telah melalui uji validasi ahli, uji praktisi pendidikan, uji coba lapangan awal, uji coba terbatas, dan uji coba luas, serta direvisi berdasarkan saran dan kritikan dari semua pihak.

Hasil angket pada tiap tahapan uji coba dijadikan dasar untuk menentukan kualitas modul dan melakukan perbaikan modul sesuai dengan saran dan komentar yang diperoleh. Hasil dari tiap tahapan uji coba modul disajikan dalam Gambar 1. dan Gambar 2.

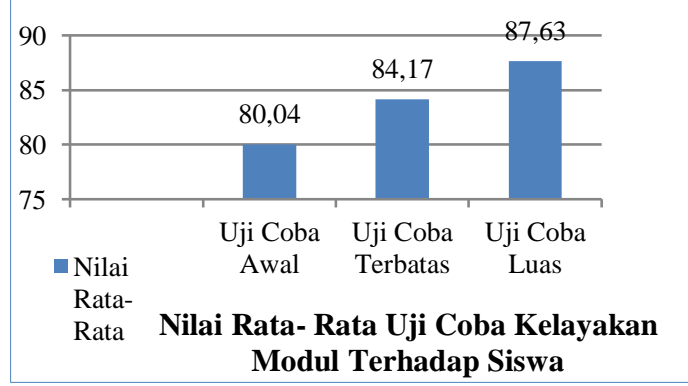

Gambar 1. Uji Coba Kelayakan Produk Terhadap Siswa

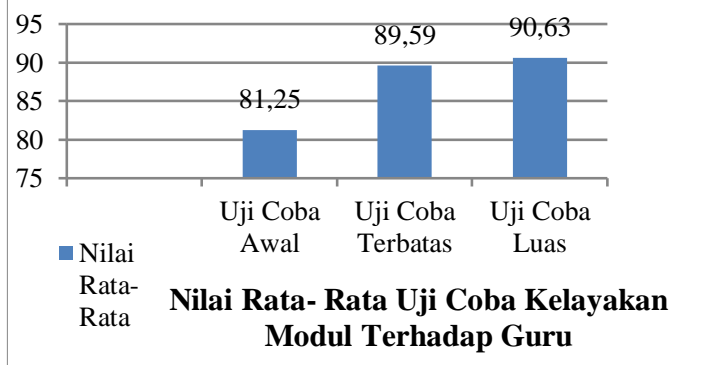

Gambar 2. Uji Coba Kelayakan Produk Terhadap Guru

\section{Hasil Analisis}

Sebelum siswa pada kelas eksperimen diberikan pembelajaran menggunakan modul, setiap siswa pada kelas eksperimen dan kelas kontrol diberikan tes kemampuan awal (pretest) baik tes aspek keterampilan berpikir kritis maupun pengetahuan untuk mengetahui kondisi awal kelas tersebut. Kelas eksperimen diberikan pembelajaran kimia menggunakan modul kimia berbasis inkuiri terbimbing, sedangkan pada kelas kontrol diberikan pembelajaran kimia tanpa modul. Model inkuiri terbimbing merupakan salah satu model pembelajaran yang sesuai dengan kurikulum 2013 dan cocok dengan perkembangan jaman. Pembelajaran inkuiri merupakan suatu rangkaian kegiatan terstruktur yang menekankan pada proses penemuan jawaban oleh siswa.

Hasil analisis terhadap kebutuhan guru, diketahui bahwa guru sudah mempunyai buku pegangan dan buku siswa yang berdasarkan kurikulum 2013, tetapi guru masih membutuhkan suatu media cetak alternatif lain yang dapat membantu siswa menjadi lebih aktif dalam setiap kegiatan pembelajaran dan meningkatkan kemampuan berpikir siswa.

Untuk membantu siswa selama pembelajaran berlangsung, diperlukan suatu media yang dapat mengembangkan kemampuan siswa dalam mengolah, menemukan, dan mengkonstruksikan data yang diperoleh siswa. Hal ini tidak terlepas dari peran guru dalam mewadahi dan menyediakan media, sumber belajar, dan model pembelajaran yang cocok dengan 
kompetensi dasar yang akan dipelajari siswa.

Pengintegrasian model pembelajaran inkuiri terbimbing ke dalam pengembangan modul kimia dapat memaksimalkan kegiatan pembelajaran siswa karena siswa menjadi lebih aktif selama mengikuti pembelajaran, sehingga siswa dapat menemukan pengetahuan mereka sendiri selama pembelajaran berlangsung.

Untuk mengetahui perbedaan keterampilan berpikir kritis dan hasil belajar siswa, pada masing-masing kelas kontrol dan eksperimen dilakukan posttest. Kemudian hasil pretest dan posttest dari masing-masing kelas dihitung gain score dan diukur efektifitasnya.

Keterampilan berpikir kritis siswa dievaluasi berdasarkan soal non-materi untuk membedakan dengan hasil evaluasi aspek pengetahuan. Soal keterampilan berpikir kritis merupakan soal khusus yang diadaptasi dari Piaw (2004) dan telah divalidasi oleh ahlinya.

Dilihat dari aspek KBK siswa, terdapat perbedaan pada kelas eksperimen setelah dilakukan pretest dan posttest yang disajikan dalam Gambar 3 dan Gambar 4.

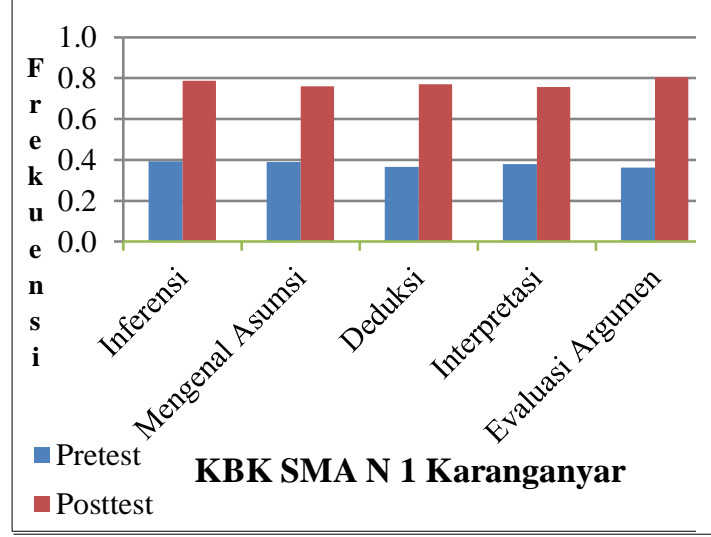

Gambar 3. Hasil Analisis Keterampilan Berpikir Kritis Siswa SMA Negeri 1 Karanganyar

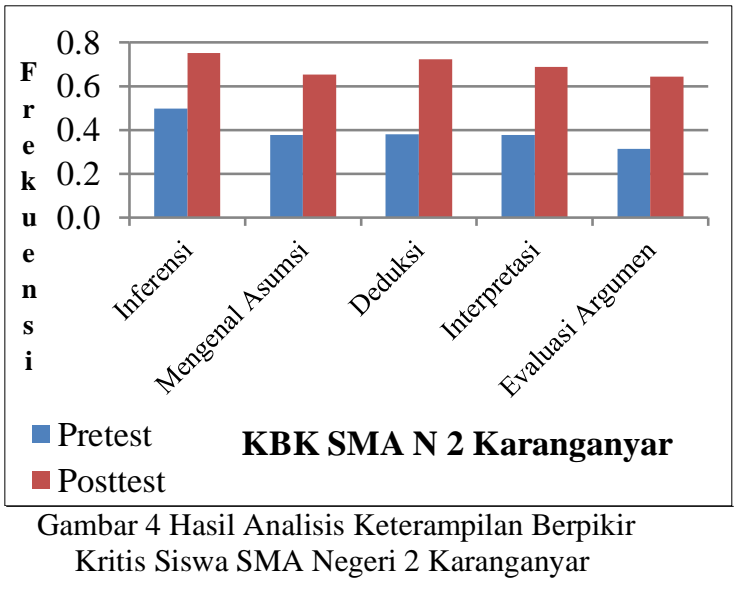

Aspek pengetahuan merupakan salah satu evaluasi terhadap keberhasilan proses belajar siswa, aspek pengetahuan dievaluasi dengan soal yang berhubungan dengan materi yang diajarkan. Hasil aspek pengetahuan siswa yang menggunakan modul kimia berbasis inkuiri terbimbing disajikan dalam Gambar 5

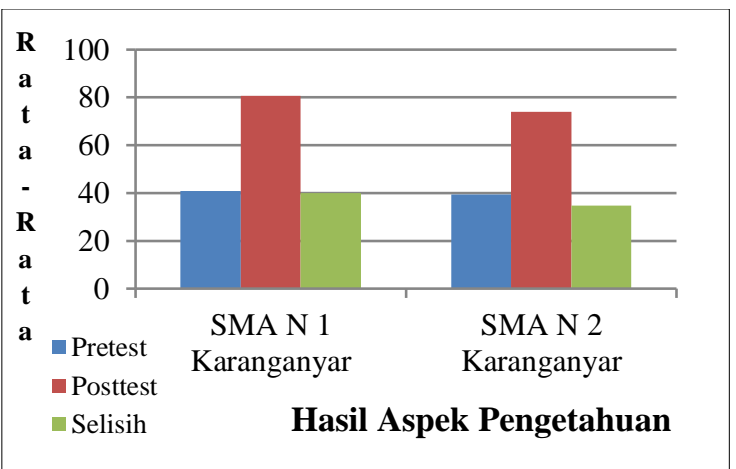

Gambar 5. Hasil Analisis Aspek Pengetahuan Siswa di SMA Negeri Karanganyar

\section{Pembahasan}

Modul dikembangkan berdasarkan hasil studi pendahuluan, yaitu studi lapangan dan studi pustaka. Hasil dari studi pendahuluan dijadikan landasan sebagai dasar pengembangan terhadap modul kimia. Kondisi pembelajaran di lapangan dapat diketahui melalui hasil pengamatan secara langsung, wawancara, dan penyebaran angket.

Hasil studi pendahuluan dilakukan dengan mencari tahu tentang kondisi pembelajaran di lapangan yang didapat 
melalui hasil pengamatan secara langsung, wawancara, dan penyebaran angket. Pengamatan dilakukan selama guru menyiapkan dan melakukan pembelajaran.

Wawancara dan penyebaran angket dilakukan kepada guru dan siswa untuk membantu mencari permasalahan yang ada di lapangan. Adapun hasil dari ketiganya adalah sekolah sudah mengacu dan menggunakan kurikulum 2013 dengan perangkat pembelajaran yang didapatkan dari pusat tetapi ada beberapa yang ditambahkan oleh guru.

Proses pembelajaran yang terjadi di lapangan adalah belum sepenuhnya mengacu pada kurikulum 2013. Hal ini dapat dilihat dari aktifitas guru yang masih menerangkan materi pada siswa, kemudian guru memberikan latihan soal dan dijelaskan langkah pengerjaannya. Ini bukanlah langkah - langkah dalam kurikulum 2013, dimana pembelajaran dipusatkan pada siswa sehingga siswa dapat aktif selama proses pembelajaran berlangsung agar siswa dapat benar-benar memahami dan menerapkan pengetahuan yang diperolehnya.

Hasil pengamatan yang dilakukan peneliti adalah, bahan ajar bantuan yang digunakan masih belum sesuai dengan kurikulum 2013, yaitu LKS yang masih menggunakan kurikulum 2006. Kurikulum 2006 mempunyai perbedaan dengan kurikulum 2013, sehingga sebaiknya dalam proses pembelajaran guru menggunakan bahan ajar yang sesuai. Untuk mencapai tujuan pembelajaran, salah satu komponen penting yang harus diperhatikan guru adalah media pembelajaran.

Hasil pengamatan terhadap buku yang digunakan oleh siswa dan guru adalah pada buku siswa, materi dan penilaian pengetahuan sudah baik, tetapi kegiatan dalam buku belum mencakup pendekatan saintifik dan belum memaksimalkan keterampilan berpikir siswa, serta belum ada format penilaian sikap dan keterampilan. Berdasarkan format dan rubrik penilaian, diperoleh hasil analisis terhadap buku siswa sebesar 83,33\% dengan kriteria bahwa hasil analisis tepat.

Sesuai dengan analisis kebutuhan yang telah dilakukan, maka modul merupakan media yang tepat sebagai alat bantu ajar dalam pembelajaran kurikulum 2013. Media modul merupakan salah satu pendamping buku ajar guru selama proses pembelajaran berlangsung. Modul yang akan dikembangkan dalam penelitian ini adalah modul dalam bentuk cetak.

Modul yang dikembangkan adalah modul kimia berbasis inkuiri terbimbing. Menurut Vlassi \& Karaliota yang melakukan penelitian untuk membandingkan penggunaan inkuiri terbimbing dan metode tradisional, menyimpulkan bahwa penggunaan inkuiri terbimbing memberikan hasil kinerja siswa yang lebih tinggi daripada metode pengajaran tradisional untuk pengajaran struktur materi (Vlassi \& Karaliota, 2013). Dalam penelitian Vainoo, Holbrook, \& Rannikmiie juga menyimpulkan bahwa modul yang dirancang khusus dapat meningkatkan motivasi belajar dan prestasi siswa (Vaino, Holbrook, \& Rannikmae, 2012). Hasil dari penelitian keduanya dapat dijadikan alasan bahwa pengembangan modul yang disesuaikan dengan kurikulum 2013 dapat membantu siswa dalam proses belajar.

Uji coba modul dilakukan terhadap guru dan siswa sebanyak tiga kali, yaitu uji coba awal, uji coba terbatas, dan uji coba luas. Hasil dari uji coba terhadap guru dan siswa memiliki rata - rata presentase di atas $80 \%$ pada tiap uji coba dengan kategori akhir modul yang sangat baik. Hal ini berarti bahwa modul kimia inkuiri terbimbing dapat digunakan dalam pembelajaran.

Efektifitas modul kimia dilihat dari hasil uji coba modul terhadap siswa yang telah memperoleh materi pada modul. Efektifitas modul penting dalam penelitian karena hal ini merupakan indikasi tercapai atau tidaknya tujuan dari pengembangan modul kimia berbasis inkuiri terbimbing. 
Modul kimia berbasis inkuiri terbimbing merupakan modul yang mempunyai kegiatan belajar yang sesuai dengan kurikulum 2013 dan dapat memaksimalkan keterampilan berpikir kritis siswa karena modul ini mempunyai kegiatan yang mengikutsertakan siswa dalam membangun pengetahuan dan keterampilan berpikir siswa. Untuk mengetahui perbedaan hasil antara kelas kontrol dan kelas eksperimen, aspek keterampilan berpikir kritis dihitung berdasarkan selisih pretest dan posttest.

Selanjutnya, hasil selisih pretest dan posttest dianalisis menggunakan SPSS 20 yang menghasilkan bahwa data kedua SMA berdistribusi normal dan homogen untuk selanjutnya dilakukan uji t.

Hasil Uji pada SMA N 1 Karanganyar adalah $t_{\text {hitung }}>t_{\text {tabel }}$, yaitu 5,03 $>1,67$ yang berarti bahwa Keterampilan berpikir kritis kimia siswa kelas eksperimen lebih baik dari siswa kelas kontrol. Hasil Uji pada SMA N 2 Karanganyar adalah $t_{\text {hitung }}>$ $\mathrm{t}_{\text {tabel}}$, yaitu 1,81 > 1,66 yang berarti bahwa Keterampilan berpikir kritis kimia siswa kelas eksperimen lebih baik dari siswa kelas kontrol. Sehingga dapat disimpulkan bahwa modul kimia berbasis inkuiri terbimbing efektif digunakan untuk meningkatkan keterampilan berpikir kritis siswa.

Modul yang dikembangkan peneliti mempunyai tujuan untuk meningkatkan keterampilan berpikir kritis siswa karena dengan keterampilan berpikir kritis yang lebih baik daripada sebelumnya dapat meningkatkan hasil belajar siswa aspek pengetahuan, sikap, dan keterampilan. Hal ini sesuai dengan hasil penelitian Suyono, dkk (2016) yang menyatakan bahwa siswa dengan keterampilan berpikir kritis dapat menyelesaikan tes pengetahuan serta memiliki sikap dan keterampilan yang baik karena siswa mampu menganalisis fakta, mempertahankan pendapat, serta memecahkan masalah. Hal ini juga sesuai dengan tujuan pembelajaran inkuiri, yaitu untuk memberikan cara bagi siswa untuk membangun kecakapan-kecakapan intelektual (kecakapan berpikir) terkait dengan proses-proses berpikir reflektif (Yuniyanti, Sunarno, \& Haryono, 2012).

Yanti (2015) menyatakan bahwa pembelajaran menggunakan modul membantu siswa lebih aktif dan tertarik selama pembelajaran serta dapat meningkatkan keterampilan berpikir kritis siswa (Yanti, Sukarmin, \& Suparmi, 2015). Keterampilan berpikir kritis siswa dapat meningkat dengan penggunaan modul karena pada setiap langkah pembelajaran di dalam modul membantu siswa untuk menekankan kemampuan berpikir mereka lebih luas dan kritis (Wijayanti, Prayitno, \& Sunarto, 2016).

\section{Simpulan dan Saran}

Berdasarkan hasil analisis dan pembahasan yang telah dilakukan, dapat disimpulkan bahwa hasil dari penelitian dan pengembangan adalah sebagai berikut: (1) modul kimia berbasis inkuiri terbimbing dapat meningkatkan keterampilan berpikir kritis siswa SMA pada materi Larutan Penyangga, (2) hasil akhir pengembangan modul adalah kategori modul yang sangat baik dan layak digunakan oleh siswa dan guru dalam proses pembelajaran materi Larutan Penyangga, (3) pembelajaran menggunakan modul kimia berbasis inkuiri terbimbing efektif digunakan untuk meningkatkan keterampilan berpikir kritis siswa berdasarkan hasil uji t, (4) Pembelajaran menggunakan modul kimia berbasis inkuiri terbimbing dapat meningkatkan hasil belajar aspek pengetahuan siswa sebesar 37,25\%; $86,96 \%$ siswa memiliki sikap dengan kategori baik; dan 92,18\% siswa memiliki keterampilan dengan kategori baik.

Saran untuk penelitian selanjutnya, apabila guru akan menggunakan modul berbasis inkuiri terbimbing, akan lebih baik apabila guru tersebut memahami terlebih dahulu langkah-langkah dan batasan bantuan dalam inkuiri terbimbing agar tercapai tujuan pembelajaran. 


\section{Daftar Pustaka}

Hosnan, M. 2014. Pendekatan Saintifik dan Kontekstual dalam Pembelajaran Abad 21. Jakarta: Ghalia Indonesia.

Daryanto. (2013). Menyusun Modul: Bahan Ajar untuk Persiapan Guru dalam Mengajar. (S. Darmiatun, Ed.). Yogyakarta: Gava Media.

Linn, M. C., Davis, E. A., \& Bell. P. (2004). Inquiry and technology. In M.C. Linn, E.A. Davis, \& P. Bell (Eds.), Internet Environments for Science Education (pp. 3-28). Mahwah, NJ: Lawrence Erlbaum Associates.

Kuhlthau, C. C., Maniotes, L. K., \& Casparl, A. K. (2012). Guided Inquiry Design: A Framework for Inquiry in Your School. Denver: Libraries Unlimited.

Rusyana, A. (2014). Keterampilan Berpikir. Yogyakarta: Penerbit Ombak.

Fisher, A. (2009). Berpikir Kritis: Sebuah Pengantar. Jakarta: Erlangga.

Tawil, M. \& Liliasari. (2013). Berpikir Kompleks dan Implementasinya dalam Pembelajaran IPA. Makassar: Badan Penerbit Universitas Negeri Makassar.

Vlassi, M. \& Karaliota A. (2013). The Comparison Between Guided Inquiry and Traditional Teaching Method. A Case Study for the Teaching of The Structure of Matter to $8^{\text {th }}$ Grade Greek Students. Procedia - Social and Behavioral Sciences 93: 494 - 497.

Vaino, K., Holbrook, J., \& Rannikmae, M. (2012). Stimulating Students' Intrinsic Motivationf Learning Chemistry Through the Use of Context-Based Learning Modules. Chem. Educ. Res. Pract. 13: 410 - 419 .

Yuniyanti, E., Sunarno, W., \& Haryono. (2012). Pembelajaran Kimia Menggunakan Inkuiri Terbimbing Dengan Media Modul Dan e-Learning ditinjau Dari Kemampuan Pemahaman Membaca Dan Kemampuan Berpikir Abstrak. Jurnal Inkuiri ISSN: 2252-7893, Vol 1, No 2: 112-120.
Yanti, F. A., Sukarmin, \& Suparni. (2015). Pengembangan Modul Pembelajaran Fisika SMA/MA Berbasis Masalah untuk Meningkatkan Keterampilan Berpikir Kritis Siswa. Jurnal Inkuiri, Vol. 4, No.3. $96-103$.

Wijayanti, T. F., Prayitno, B. A., \& Sunarto. (2016). Pengembangan Modul Berbasis Berpikir Kritis disertai Argument Mapping pada Materi Sistem Pernapasan untuk Meningkatkan Kemampuan Berpikir Kritis Siswa Kelas XI SMA Negeri 5 Surakarta. Jurnal Inkuiri, Vol. 5 , No.1: 105 - 111. 